\title{
What is the job of the editor of a plastic surgery journal?
}

s an author, I have always thought of the Editor of a reputed medical journal as a wise, old and experienced medical scientist, who has been there and done that too, and so is a fountainhead of knowledge with absolute authority to decide what should appear in print and what does not deserve the distinction. Today, when I am the editor, I know none of my previous assumptions were true. Yes, it is a serious job and one has to develop these unique genes as days go by, but what is most important is that it is a highly speciality-specific, region-specific and language-specific job. I regard the role of editor as being that of a steward - the editor is responsible for protecting and enriching the asset for the good of the community, now and into the future. To be entrusted with this responsibility of editing a plastic surgery journal is humbling, and it is a signature honor for any plastic surgeon. So, what is expected of an editor of an English language plastic surgery Journal? As I see my role in the Indian Journal of Plastic Surgery (IJPS), my priorities are:

1. To encourage a whole new generation of plastic surgeons to document their work scientifically and accurately for posterity. Any cleft lip and palate (CLP) unit in India treats more CLP patients in a month than the whole of Norway and Sweden does in a year. Yet, there are more publications on CLP from these countries than there are from the whole of India. This reluctance to document is a crime and surgeons can no longer plunder our cleft resource and pay nothing back in return. The Journal, with a special CLP issue, encouraged first-time authors who are otherwise outstanding podium orators. I believe that an equally important role for the editor is to encourage and support both promising new research thrusts and promising young scholars, as these will determine the future of our burgeoning specialty.

2. To guard the frontiers of plastic surgery so that the so-called grey areas are not encroached by others. A responsible plastic surgery journal acts as a vanguard to the specialty's porous and fragile borders, fending away tenacious poachers from other specialities. Thus, papers on hypospadias and epispadias, invited articles on wrist trauma and small joint replacements and special issues on rhinoplasty, maxillofacial trauma and head and neck reconstructions are a considered strategic response of the IJPS. Through these publications, we have started to assert our legitimate rights on our territory with authority and distinction. At no stage are we attempting to establish hegemony or monopoly; quite to the contrary, we are setting standards and challenging others to match us! While remaining a firm believer of multidisciplinary management, we are simply trying to establish our leadership role.

3. To establish a harmonious balance between clinical plastic surgery and plastic surgery research so that the researchers are aware of the need of the clinicians, and clinicians in turn are kept abreast of the frontiers of research. Stem cell research, research on bionic arms and eyes, research on flap physiology, perfusion pressure of perforators and anatomy of skin, vessels and nerves should always be encouraged. Through publication, decisions and policies that maintain high standards and that establish the journal's "taste" for research, the editor should be able to encourage the readers to develop the same "taste".

4. To keep the speciality together is another purpose of a plastic surgery journal. My generation has seen the disintegration of general surgery and we did not like it. While she should have looked like a proud mother of so many outstanding superspecialities, today she appears as a weak, depressed, anaemic and osteoporotic old lady! Yes, we are all in favour of strengthening of subspecialities, but let this in turn strengthen the mother speciality and not weaken it. Why should a craniofacial surgeon share more commonality with a neurosurgeon than his own fellow plastic surgeon who perhaps is into aesthetic surgery or burn management? We should encourage him to choose our Journal for publishing his work, 
rather than send it to a craniofacial journal. We are surely offering more number of eager and curious eyeballs, then why are we losing these good papers?

5. To navigate the speciality towards the future by encouraging the emerging trends and yet keeping the fads far away. The Journal should encourage and invest in emerging research themes. Researches on nanotechnology, tissue engineering and minimal invasive plastic surgery are, to my mind, the trends we need to promote. The editor should be ready to encourage and support unconventional papers that have promise but might easily be killed by referees. An important role for the editor is to take some calculated risks with papers with an uncertain but potentially high upside. This is indeed much like the Derby, and the journal editor has to bet on the winning horse every time even when it is not tipped to win!

6. To evaluate newer technology and see whether it is truly beneficial or yet another attempt at clever repackaging of an old and obsolete idea. Technology today can fix things without touching them and touch things without seeing them. A journal should be very careful while dealing with clever science that is in search of use. While necessity is the mother of invention, strategy should be its father. A journal should identify the strategy-less, market-driven technologies and baseless jingoism that usually accompanies them and refrain from affording them the legitimacy they so keenly seek. Yet, we have to pick up useful emerging technologies on the horizon, lest we are bypassed by them. Opening our mind to what is good, yet closing our doors to what is not, is surely one of the most difficult jobs of an editor.

7. To ensure ethics in practice and publication. The Editor should aim to encourage ethical practice skills in their authors and readers, which should be abundantly apparent in the printed text. Adherence to the norms of the ethical committees while planning research, honest and easily understandable statistical analysis that proves the obvious and does not manipulate figures to make the conclusions vague and to write an original text and not present a mosaic of "cut-paste" paragraphs from 50 previously published works should always be encouraged. The ultimate aim of publication in our medical field is to improve patient care. The Journal should avoid "me too" publications.
8. To improve our visibility on the internet and, thereby, the number of citations and impact factor of the journal. The internet was invented by the Americans and that is where our problems started. Common search engines like MSN and Google pick "fetal" earlier than "foetal" and "etiology" better than "aetiology". Although I am absolutely certain that English language plastic surgery journals should remain English and these words should find no place in the text, Key Words should also be in American English for the sake of visibility.

9. To get ready for a generational change in documentation. We are the last generation of surgeons who are felling trees and printing paper journals for such a small target audience. All this is changing and changing for the better. With the introduction of the electronic journal, we in IJPS are not only be documenting text and two dimensional photographs, also to see three dimensional images, movies and videos. Lengthy descriptions of the function of the reconstructed hand will be replaced by a video and that of a reconstructed palate by an audiovisual file. The editor has to navigate the journal in the transition time with studious astuteness such that the old timers do not feel offended and the newer generation is automatically attracted.

The Editor of a plastic surgery journal has:

1. Responsibilities to the Society of Plastic Surgeons - to represent the opinion of the members and to protect the interest and dignity of the community.

2. Responsibilities to the authors - to ensure that their submissions get a timely and unbiased review and are also value added by the editorial and referee inputs.

3. Responsibilities to the reviewers - towards keeping their identity concealed and keeping them away from unnecessary hassles.

4. Responsibilities to the readers - to give them an unbiased opinion on all controversial issues and present both sides of the coin and to ensure that good science and new knowledge can be provided to the readers within a reasonable time-frame.

5. Social responsibilities to the people - by promoting useful and safe products and procedures.

I dream of a medical world populated with concepts, principles and models that originated in research first 
published in our Journal. I look forward to a day when scholars will credit the Journal with being instrumental in their success in terms of helping them to improve and disseminate their research. I am hopeful of a day when plastic surgeons practicing across seven seas will tell their peers that they picked up the smartest techniques and the safest technologies from our journal. With time, we will get a larger share of the best papers of archival quality from the best researchers.

In the healthcare sector of the future, less emphasis will be placed on curing illnesses than on prevention and well-being. Beings and machines will merge, with bionic limbs representing the first step towards this end. Body and consciousness will be rewired and reprogrammed. The natural body and the artificial intelligence will form an unique combination of hardware and software, creating mechanical humans and human machines. Death might become optional, with laboratory-designed parts increasingly replacing diseased organs. Stem cells and gene manipulation will decode the secret of selfhealing, changing the prevalent treatment pattern of today. But, human evolution will continue and result in new intelligent beings. In this glorious future of plastic surgery, I would like to be an eager participant and steer my Journal and my readers to a world where no one has ever gone before!
Surajit Bhattacharya Editor, IJPS, Sr. Consultant Plastic Surgery, Sahara Hospital, Lucknow, India. E-mail: surajitbh@yahoo.co.in

\section{Author Help: Online submission of the manuscripts}

Articles can be submitted online from http://www.journalonweb.com. For online submission, the articles should be prepared in two files (first page file and article file). Images should be submitted separately.

1) First Page File:

Prepare the title page, covering letter, acknowledgement etc. using a word processor program. All information related to your identity should be included here. Use text/rtt/doc/pdf files. Do not zip the files.

2) Article File:

The main text of the article, beginning with the Abstract to References (including tables) should be in this file. Do not include any information (such as acknowledgement, your names in page headers etc.) in this file. Use text/rtf/doc/pdf files. Do not zip the files. Limit the file size to $1 \mathrm{MB}$. Do not incorporate images in the file. If file size is large, graphs can be submitted separately as images, without their being incorporated in the article file. This will reduce the size of the file.

3) Images:

Submit good quality color images. Each image should be less than $\mathbf{2 0 4 8} \mathbf{~ k b ~ ( 2 ~ M B ) ~ i n ~ s i z e . ~ T h e ~ s i z e ~ o f ~ t h e ~ i m a g e ~ c a n ~ b e ~ r e d u c e d ~ b y ~}$ decreasing the actual height and width of the images (keep up to about 6 inches and up to about $1800 \times 1200$ pixels). JPEG is the most suitable file format. The image quality should be good enough to judge the scientific value of the image. For the purpose of printing, always retain a good quality, high resolution image. This high resolution image should be sent to the editorial office at the time of sending a revised article.

4) Legends:

Legends for the figures/images should be included at the end of the article file. 